\title{
ISSUES OF OWNERSHIP AND ACCESS IN THE WORK OF JOHN MUIR, JOHN BUCHAN AND ANDREW GREIG
}

\section{Terry Gifford*}

Abstrat: This essay discusses two novels by two writers from Scotland: John Macnab, by John Buchan (1926) and The Return of John Macnab, by Andrew Greig (1996). These novels are examined through the lenses of ecocriticism having in mind a discussion of issues of ownership and access of the land. That Nature cannot be conceived except through the frames of culture is the main focus of the discussion.

Keyvords: Ecocriticism; Nature and culture; Scottish writers

In 1849, when John Muir was eleven years old, his father announced to him that he was to leave the Scottish town of Dunbar where he had grown up, 'for we're gan to America the morn' (Gifford 1992: 42). At least, that was how the 70 year old Muir dictated it to the secretary of the American railroad magnate, E. H. Harriman who realised that this was the only way he was going to get any kind of autobiography out of Muir: the short book that did not progress further than The Story of My Boybod and Youth (1913). Twelve years earlier Muir had published what he considered to be a much more important book, Our National Parks (1901). This book opens with the now famous words first published in 1898 (Muir 1898: 15):

The tendency nowadays to wander in wildernesses is delightful to see. Thousands of tired, nerve-shaken, over-civilized people are beginning to find out that going to the mountains is going home; that wildness is a necessity; and that mountain parks and reservations are useful not only as fountains of timber and irrigating rivers, but as fountains of life (Gifford 1992: 459).

In this book Muir set out the principles for the notion of a series of 'nation's parks' that would preserve some nationally important landscapes and ecosystems for the 're-creation' of future generations. Yosemite National Park, which Muir was instrumental in creating in 1892, was not the first to be

former Reader in laterature and linvironment at the Lniversity of leceds (now retired); director of the annual International lestival of Mountainecring literature at Bretton I lall College/ (lniversity of

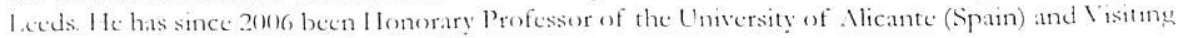
Profesior. Liniversity of Chehester, LK. 
so designated, although it was the first to be preserved for the essential reasons of conservation and recreation. In 1872 Yellowstone had been created a National Park, but this was in order to prevent commercial exploitation by the owner of Old Faithful, the geyser attracting the first tourists to the wonders of the West. Thus issues of ownership and commercial interests in landscape were at the heart of the reasons for the creation of the world's first National Parks, a concept originating from a Scot transplanted to America.

In 2002 Scotland gained its first National Park designation in the Loch Lomond and The Trossachs National Park' and this has been followed in 2003 by the 'Cairngorms National Park'. John Muir might have been as perplexed as his American followers are, at the lateness with which his notion of National Parks has been taken up in the land of his birth. In fact, this observation highlights the confused and complex issues of private ownership and restricted access in Scotland's wild land, especially following the placing of the Cullin mountain range on the Isle of Skye on the market for one million pounds and the high-profile purchase of Ben Nevis by the John Muir Trust, a Scottish conservation organisation with nearly 10,000 members and supporters, which buys and manages wild estates in the name of John Muir. Ironically, the John Muir Trust, in the context of contemporary Scotland, opposes the designation of National Park within an arbitrary boundary of land in the Highlands because of the implications for wild land outwith those designated National Parks in the remainder of the Highlands. Whilst contemporary Americans struggle to find a way to put the clock back and ban cars from the Yosemite Valley, the Scottish authorities are secking to make a National Park of the Cairngorms massif for which they have recently approved the building a funicular railway to its summit plateau.

In 2003, on the eve of the Cairngorms National Park designation, the boundary was hastily redrawn to exclude $25 \%$ of land that Scottish Natural Heritage had thought essential to the park's integrity. The director of the Ramblers' Association Scotland pointed out that the land to be excluded from National Park controls was owned by 'powerful land-managing interests' who had also previously 'been very active behind the scenes in persuading the Executive to abandon much of the agreed consensus that had emerged from the public consultation process' (Wild Land News, Winter 2002/3, No 56, p. 16). Invoking the name of John Muir in a contemporary Scottish context exposes a complex of issues that have a persistently resonant history and a deep cultural reach. The issue of access to mountains and moorland, that in 
privately-owned Scotland is inevitably also an issue of ownership, has been a constant subject of debate since John Muir left Scotland in 1849. This has often been conducted in subtle forms that are bound up even today as much with the British class system as with postcolonial attitudes to wealth.

Issues of access and ownership in the Highlands were the background to a novel by the Scottish writer Andrew Greig published in 1996, The Return of John Macnab, which took its title from the central mysterious character in John Buchan's novel of 1925, John Macnab. A comparison of the two novels reveals not only the historical differences and similarities in radicalism on issues of ownership and access in the Highlands, but the problem of finding a connected relationship with a national landscape when nature cannot be conceived except through the frames of culture. The later novel may be more self-aware of its cultural frames in a postmodern manner, but could it be argued that Buchan's novel might actually have made a clearer and more lasting political analysis? More crucially, is either novel able to escape the cultural frames of its time to offer anything like a resolution for the future? Does the direct experience of landscape that drives these two narratives provide a larger, less explicit frame than the concepts of ownership explicitly engaged by Buchan and Greig as their themes? Indeed, could this narrative drive of active engagement with Highland landscape provide the basis for a reconception of what 'the Highlands' might mean in the long-term, by indicating that access is ultimately more important than ownership?

John Buchan's plot playfully challenges the concept of ownership of wild Scottish landscape. The first chapter is titled 'In Which Three Gentlemen Confess Their Ennui' because, as one of these three aristocrats says, 'There doesn't seem much worth doing since the war' (135). So they decide to launch their challenge, in the name of one John Macnab', to poach a salmon or a stag from three estates which adjoin that of one of their number where they will be based. Because they are 'gentlemen' the letter issuing their challenge to the incumbents of each estate states that 'the animal, of course, remains your property and will be duly delivered to you'. But the whole point of the challenge is based upon the assumption that the owners will defend their 'property' upon which their estates' reputations rest, from the threatened theft by the wittily named John Macnab'. Indeed, the honour of each estate, is under challenge precisely in relation to the owner's ability to protect his property from theft. The sport for which each estate's land is maintained, specialising in salmon and deer, is subverted by the meta-game of the John Macnab enterprise. 
Buchan has much fun with voice and language in emphasising the class elements in this narrative which is set in motion in a London club and played out in four Highland estates whose pattern of ownership would have changed little since John Muir left Scotland. The estate used as a base is owned by 'that ebullient young man' Sir Archibald Roylance, the Conservative candidate for this Highland constituency in which one Tory estate-owner describes the electorate as 'obstinate reactionaries ... voting Liberal since the days of John Knox' (107). Old Claybody, owner of the Haripol estate, is also an English laird who is absent most of the time, but wears an 'aggressively new' kilt when in residence for the summer. His son, Johnson, represents the most extreme and reactionary attitude towards land ownership, which his neighbours feel 'needs taking down a peg or two'. Colonel Alastair Raden, 'a real old Highland grandee' is owner of Glenraden and father of the resourceful Janet, whom he refers to as 'a bandit'. Strathlarrig's owner is in India, and, in a concession that 'there's no doubt Scotland is changing' (108) as one character complains, the house is rented for the summer to an American family, the Bandicotts. Only the servants have Scottish voices and at one point an aristocrat puts on a Cockney accent to pretend to be a tourist taking photographs. (Of course, being an owner of landscapes he does not actually know how to use a camera. This deft touch is typical of Buchan's gently satirical humour.) In his representation of Highland estate owners and summer occupants, Buchan makes it clear that all have their real business elsewhere, mostly in London. Even the Radens retreat to other estates in England for the hunting in the winter. In Buchan's novel the Highland economy - the management of this landscape - is entirely in the service of the leisure of the British governing class.

Nevertheless, Buchan is keen to raise the issue of ownership at every opportunity. At the crucial discussion of the implications of this challenge, when John Macnab has been successful in his challenges and has been revealed to have been three nationally known aristocrats, Johnson Claybody (Buchan is wickedly Dickensian in the naming of his characters) says: "There may be a large crop of Macnabs springing up, and you'll be responsible. It's a dangerous thing to weaken the sanctities of property' (244). On three occasions the term 'Bolshevik' is invoked by landowners in response to any challenge to current ownership. The vulnerability of his class is exposed uncomfortably to his neighbours by Johnson Claybody's protesting too much. His mother senses in her son's anxiety 'a theory of life' based upon a 'mercantile creed' that is not her own. She asserts that wealth should be taken for granted, 
whereas her son is 'making property a nightmare, for you are always thinking about it' (244). The logic she develops produces a line of argument that is almost Buchan echoing Jane Austen: 'It is so vulgar not to keep money and land and that sort of thing in its proper place. Look at those splendid old Jacobites and what they gave up. The one advantage of property is that you can disregard it' (244). Buchan's satire is completed by the acceptance of this statement by almost all of the assembled company: 'This astounding epigram passed unnoticed save by Janet.'

Buchan gives to Janet the most radical speeches in the novel. Her sense of the changes taking place in the Highlands following the war derives from her observation of an abdication of moral responsibility by the owners themselves: 'The old life of the Highlands is going, and people like ourselves must go with it. There's no reason why we should continue to exist. We've long ago lost our justification' (134). Janet goes so far as to draw the charge of Bolshevism from Sir Archie when she says of her long-established Scottish family, 'Somehow the fire went out of their blood, and they became vegetables. Their only claim was the right of property, which is no right at all' (134). But redistribution of wealth is not on her agenda, merely putting new fire back in the old blood: 'I don't mean that we want some silly government redistributing everybody's property. I mean that people should realise that whatever they've got they hold under a perpetual challenge. Then we'll have living creatures instead of mummies' (135). The use of the word 'silly' indicates Buchan's placing of this argument: it is both the youthful idealism of a girl and a serious dismissal of government interference in the moral duties of the aristocracy. They will sort themselves out, Buchan implies, from a framework of class responsibility that closes down the debate in the novel's final scene when they all 'do the decent thing' and the reader is reassured that, of course, there was never any real risk to either property or reputations. A story is concocted for the press, apologies are made all round, Johnson admits that he has made rather a fool of himself and dinner is served by servants who are nameless and invisible. Buchan can only allow his satire to go so far; in 1925 a girl cannot be given arguments that are to be taken as a serious threat to the principles of property upon which the British establishment is founded.

But what role in Buchan's novel has been played by the land itself? The Highland landscape is both a background pastoral 'attraction' of the novel and an essential element of the physical difficulty of the project of John Macnab. Buchan, as a writer of novels of action, does not waste much 
space with landscape description. When he does, it is for one of two purposes. It is necessary to the terms of action, as in his set-piece description of a dawn in the 'dark wastes of wood and heather': 'Darkness gave place to the translucence of early dawn: the badger trotted home from his wanderings: the hill-fox barked in the cairns to summon his household; sleepy pipits awoke ...' (72). Or it is to advance his romantic sub-plot, as when Sir Archie suddenly realises that he has some feelings for Janet which, as an aristocratic male, he struggles to comprehend: 'The young man, who had no skill in analysing his feelings, felt obscurely that she fitted most exquisitely into the picture of rock and wood and water, that she was, in very truth, a part of his clean elemental world of the hill-tops' (135).

Sir Archie is a naturalist, 'as eager to stalk a rare bird with a field-glass as to lead a rifle up to deer' (34) and thus 'his clean elemental world' refers not to ownership so much as affinity. But the word 'picture' is the real indication that he thinks of this affinity and, indeed, his romantic feelings, in the cliché of the picturesque pastoral. Buchan's landowners may have 'a pretty accurate knowledge of the country-side', but its fundamental meaning for them is that of a pastoral playground with all the imposed idealisation of the picturesque. The very language used to refer to the land makes it a large sports-field. It is divided by 'marches' (boundaries) and 'beats' (rivers). Sportsmen and naturalists alike are consumers of land that serves the function of an escapist idyll. Indeed, Janet herself uses the term 'idyllic' of the boy, Benjie, who makes heather besoms: 'He and his old pony made a more idyllic picture than ever in the mellow light of evening, almost too conventionally artistic to be real' (79). And this is the very 'picture " that is used for the cover of the 1956 Penguin edition (and the facsimile edition currently in print), thereby suggesting that the novel might serve a pastoral function for the reader. The national 'evening papers' in this novel may know, as Buchan obviously does, that the public interest in the Highlands requires information on 'the sport of deer-stalking, Celtic mysticism, the crofter question, and the law dealing with access to mountains' (98), but Buchan's apparent challenge in this novel to the fundamental issue of ownership of Highland estates is itself only a game. The gently satirical humour is ultimately closed down as the pastoral narrative ends with the restoration of rights and reputations, and Janet's most radical speech is forgotten as these landowners return to the real business of earning money in the City or the city. The novel has enacted the classic pastoral movement of retreat and return: alternative notions of society, playfully 
explored in rural retreat, are ultimately distanced by the return to 'court' where business is done and to normative 'reality'.

For the non-aristocratic, non-estate owning reader - for the contemporary crofting reader of Buchan, perhaps - the newspapers' issue of 'access to mountains' and this elitist sport management of Highland land remains unresolved. The real function of the novel has not been to raise its explicit (but playful) challenge to ownership, so much as to tantalise with the experience of access, in an idealised escapist form in which the land is both a challenge and a test, clearly valued for the intimacy of experience it can offer those who know how to read it for the purpose of what the British governing class of 1925 called 'sport'. What Buchan has given his readers is a sense of what an intimate experience of this landscape can be like, although within a limited frame of what it can mean. By 1996 Andrew Greig's readers would have a wider sense of what it can mean, not only through a greater diversity of leisure uses, but through a more complex public knowledge about its meaning as ecosystem. Both of these lie behind the modern politics of ownership, and access for modern sport, although Greig does not explore them beyond having technical rock-climbing and paragliding as instruments in his plot. Issues of access and ownership remain little changed, although the Highland economy - 'Scotland Heritage UK plc', as one of Greig's characters calls it - is now more dependent upon access to the hill country for an expanded tourist economy. Again, this is not explored by Greig, but accepted as the context for his plot, which is simply a modern re-enactment of John Macnab. For all his postmodern knowingness as the author/narrator ('I enter Save File and the return of John Macnab is done.' 273), Greig is writing a thriller in the same genre as Buchan. For all the postmodern disruption of the cover painting on the 1996 book, what emerges from the mist on that cover, in random relationship to each other, are pastoral icons of deer, dove, broken tree, mountain and a man, apparently in tweeds.

But in 1996 a novel must warn the reader against the notion of the Highlands as pastoral by the third paragraph of the first page: 'He looks up at the hills that circle the town, sees the upper slopes are purple with heather and reminds himself he mustn't say so. Certain things about his country invite clichés. Certain things about his country are true' (1). In the process of telling us the name of his first character, the author's guarded recognition of the beauty of the setting of his novel is continued in the sentence that follows: 'Nevertheless, Neil Lindores nearly smiles as he takes out a suitcase and 
backpack.' Greig's fear of writing pastoral comes close to producing bathos in 'nearly smiles'. The phrase about 'Scotland Heritage UK plc' is given to a character driving into a beautiful sunset. Greig's description of a beautiful dawn in the Cairngorms is qualified by a direct challenge to the reader: 'go take a look if you don't believe me' (39). It is also undercut by the negativity that must, it seems, emerge from the image of the hills as whales: 'A beautiful disaster slowly dying under its own weight' (39). The negative feeling here seems more important than meaning. Unlike Buchan, Greig is concerned to counter the dreaded pastoral clichés of the tourist consumer with recurrent anti-pastoral images. There are ten references to midges and one to a cleg in this novel. 'Drizzle and midgies [sic]' is one character's counter to the attraction of 'magnificent hills' (92).

On the other hand, the positive experience that the Highland landscape can offer to people underpins the novel's repeatedly raising modern issues concerning access and ownership. Why, else, would these be issues at all, if not for the assumption that open access to direct experience of wild land is 're-creating' in Muir's sense? Indeed, at one point Neil Lindores is given the thought that experience of this wild land will itself be a source of healing for not just his own negative sense of his life - that his hourglass is running out but that of the Scottish psyche in general:

What a depressingly Scottish image. Its negativity was another thing that was true about his country: It went with tholing, bearing, putting up with, and taking a certain satisfaction in the expected bad news when it came. He sensed it was a wrong picture. He was groping for another, still true but more affirmative. Perhaps somewhere in the hills it would come to him. (124)

In fact, Neil, who has not really accepted a new life for himself since his wife died, finds in his role as one of the John Macnabs a connection with the land that is personally healing:

For a while he just sat looking down the slope at the burn flashing and the khaki-coloured hills beyond. There was nothing virtual about this reality. This was as real as a warm dead bird in his hands. This belonged to itself, not to Maurice Van Baalen. On this ploy for once they were the creators, not consumers, and that made all the difference. That's where the healing lay. (167) 
Quite where the healing lies for Scottish culture is not explicitly imaged in the way it is here at a personal level - unless this is the point: being personally creative in finding a mode of connection with the Scottish landscape that 'belongs to itself', perhaps through political action that challenges the Van Baalens, the Dutch, Arab and royal landowners who are challenged in the 1996 novel. Perhaps the very perception of land that 'belongs to itself' is healing in the ecological sense of relating to an ecosystem that both includes and is beyond the human species. But such a relationship presumes access to the ecosystem and in Scotland access is controlled by ownership.

One of Greig's John Macnabs is Murray Hamilton, who is the later novel's radical. A socialist councillor who resigned over the introduction of the poll tax, he is frustrated with conventional democratic politics. So it is significant that Greig has chosen three Scottish landowners who do not have a vote in Britain. For Neil and for Alistair, the other two John Macnabs, the challenge is about escaping boring lives, much as it was for Buchan's aristocrats. But early in Greig's novel Murray declares that for him, 'This is about land access, land use and land ownership. The fuckin Criminal Justice - right?' (14) Even before this declaration Greig's characters twice refer to the Criminal Justice Act of 1994 which had introduced a new law of Aggravated Trespass. This is also much alluded to in the first half of the novel until it is tested by a televised demonstration in 'the Battle of Maiden Braes' and found to be as hard to define as the traditional 'grey area' of Scottish trespass law. Greig brings in the Right to Roam movement and the Ramblers' Association, as well as animal rights activists, in the background to his plot, which Murray characterises as 'just a wee blow against everything that was being taken away' (43). The passage of the Criminal Justice Act by the Thatcher government was felt by people like Murray to be actually 'taking away' access to wild land - that which, as he puts it, 'should never be owned, like land and water and people's lives for starters' (42). In an equally topical aside, Greig makes an indirect reference to the Letterewe Accord, a real access agreement signed in 1993 by Paul Van Vlissingen, the Dutch owner of the Letterewe estate in Torridon, that includes what is known as the Great Wilderness. Greig comments on the 'Access Concordat' agreed by his novel's Dutch landowner that 'it was extremely vague, and being purely voluntary had no powers to bring more strop.y estate managers into line. The struggle wasn't over yet' (113).

So what is achieved by Greig's exploration of issues that might be raised by modern John Macnabs? The narrative might be said to offer three 
answers to this question. First, at a personal level there is that healing process of taking the initiative creatively. Neil concludes that 'it didn't make everything all right, but it helped' (168). Greig's narrative demonstrates this for each of the character's lives, but it might also be argued that this is a function of the book itself. The second answer from the narrative implies that 'it helped' at a political level: 'John Macnab', Murray reflects, 'raised issues of land use, land access and land ownership in Scotland in a way years of doorstepping couldn't' (80). Greig's willingness to bring into his thriller the topical context of the access and ownership debate in 1996 was an act of raising awareness rather than exploring solutions. When Murray says to himself 'maybe that's the way to go', he's also aware that access and ownership are different issues, as he indicates when he says that he would be unhappy if access was all they had raised publicity about (268). In saying this he makes the third answer to the question of the Macnabs' achievement. Ownership has hardly been challenged by their activities, although the novel itself has revealed how little has changed from Buchan's debate about property in the Highlands. Buchan's original political analysis remains in place: any challenge to notions of property ownership might as well be considered as 'Bolshevik' and the moral responsibility of owners (the Dutch, Arabs, Americans, English and Scots who might make an 'Access Concordat') is where the current solutions to the access question remains. Greig's novel, for all its topical background, brings no new ideas to a resolution of the problem that his character Murray posits as: 'who owned what should never be owned'.

When, in an interview at the time of the book's publication, I challenged Andrew Grieg about the marginalisation of Murray's voice - his being positioned as 'a republican' just as Buchan evokes Bolshevism in relation to the radical arguments in 1925 - he pointed out that, in fact, 'there's not even a single dissenting voice from the radical in The Return of John Mainab, but I'd not wanted to get up on a tub and preach' (interview 4. 12. 1996). He went on to outline a number of precise requirements that might be placed on owners of Highland estates that would 'bring them into line with the rest of Europe and countries like Norway, for example', indicating a sharp interest in solutions for which he felt his novel could not be the vehicle. He referred me to Andy Wightman's then recent book, Who Owns Scotland? (1996).

When John Muir made his only return to Scotland in 1893, it was from a steamboat bound for Norway out of Oban that he observed Highland flora for the first time. He knew that he needed direct contact to learn from 
the Highland landscape: 'I have not yet climbed the Scotch hills to find out much about heather' (Gifford 1996: 383). As he wrote from the boat, his impulse was an old one that now presents a modern issue in the access debate: 'O how I would like to camp out on these shaggy hills' (ibid). In his letters he did not mention that his notion of National Parks might be applied in a Scottish context. Whether or not National Parks are a solution for the Highlands remains to be seen and Greig's novel avoids this highly contested policy. I have argued that the drive of both Greig's and Buchan's narratives is based upon a game through which the reader is brought into a sense of connectedness with wild land that clearly provides what John Muir called 'recreation'. Walking in the Highlands can be dismissed as an escapist leisure activity, affordable only to those who work in another environment, although in 1998 Scottish Natural Heritage reported that it was worth $£ 361$ million and 13, 350 jobs in Scotland. But few would deny the healing power of contact with the hills (Muir's 'fountains of life') that underpins both Greig's and Buchan's novels. This seems to be at its most powerful when the land can be experienced as 'belonging to itself', as Greig puts it, whoever is the actual owner. In Buchan's John Macnab culture, in the form of sport and ownership, is prior to nature and a pastoral novel is the result. In The Return of Jobn Macnab nature, especially in form of the midge and the weather, is sometimes presented as prior to culture to produce an anti-pastoral corrective. But what a reconception of 'the Highlands' might offer is a 're-creational' healing experience in which culture is attuned to nature and nature is perceived as including culture - that is to say, when humans find a right relationship for their culture within the other cultures and ecosystems of nature. This is what I have called a 'post-pastoral' mediation of nature (including landscape) in literature and it is what the John Muir Trust is working towards as a practical management aim for the harmony of humans and wild land. For this to be possible, the narrative drive of these two novels would suggest that perhaps management for the right kind of access is ultimately more important than the issue of ownership.

In a post-pastoral visionary passage, Greig describes Neil undertaking a meditation exercise that might stand as an image of an experience of egoreduction that nonetheless remains connected to its 'beloved country' in an integrated relationship with all its ecosystems - a sense of the physical land of Scotland as 'a centre somewhere that holds you together':

Visualize the body the size of the room now. Drifting out through the walls, the size of the hotel. How light 
that would be. Now the size of the town, hovering over it like a fine mist, the wind blowing through the pores as the body drifts without harm through the streetlamps and hilltops, expanded so much now it covers the whole Spey Valley, the whole Cairngorms, the whole beloved country, the body so huge and light and empty it's very nearly nothing but never quite nothing for there's a centre somewhere that holds you together, so nearly nothing but not quite. (99)

\section{REFERENCES:}

Buchan, John. Jobn Macnab. London: Penguin, 1956 [1925].

Gifford, Terry (ed.). John Muir: The Eight Wilderness-Discovery Books. London:

Diadem, 1992

Gifford, Terry (ed.). John Muir: The Life and Letters and Other Writings. London: Bâton Wicks, 1996.

Gifford, Terry. Pastoral. London: Routledge, 1999.

Greig, Andrew. The Return of John Macnab. London: Headline, 1996.

Greig, Andrew. Unpublished interview with TG, 4 December 1996.

Muir, John. 'Wild Parks and Forest Reservations of the West'. Atlantic Monthly', no. 81 , January $1898,15-28$.

Scottish Natural Heritage. Jobs and the Natural Heritage: The Natural Heritage in Rural Development. Perth: SNH, 1998.

Wightman, A.D. Who Owns Scotland? Edinburgh: Canongate, 1996.

The John Muir Trust, FREEPOST, Mussleburgh, EH21 7BR. www.jmt.org. 